\title{
Communication
}

[Comunicação]

\section{Occurrence of Tetrameres confusa (Nematoda, Tetrameridae) in Ara ararauna (Psittacidae)}

[Ocorrência de Tetrameres confusa (Nematoda, Tetrameridae) em Ara ararauna (Psittacidae)]

\author{
R.J. Silva ${ }^{1}$, T.C.G. Oliveira-Sequeira ${ }^{1}$, C.C. Gurgel ${ }^{2}$ \\ ${ }^{1}$ Departamento de Parasitologia - Instituto de Biociências - UNESP \\ Campus de Botucatu \\ Distrito de Rubião Júnior, $\mathrm{s} / \mathrm{n}$ \\ 18618-000 - Botucatu, SP \\ ${ }^{2}$ Departamento de Clínica Veterinária - FMVZ - UNESP - Botucatu, SP
}

The occurrence of Tetrameres confusa Travassos 1917 (= T. americana (Cram, 1927) Baylis, 1929) (Nematoda, Tetrameridae) in a new host, Ara ararauna Linnaeus, 1758 (Psittacidae), a species commonly known as Arara Canindé or blue-and-gold macaw is described in this manuscript.

The nematodes were collected from a specimen of A. ararauna from Botucatu, State of São Paulo, Brazil, during the necropsy performed at the service of ornithopathology of the Veterinary Hospital, Faculdade de Medicina Veterinária e Zootecnia, Unesp, Botucatu. The causa mortis was an accidental cervical column fracture. Examination of the digestive tract revealed the presence of filiform worms in the proventriculus lumen, as well as numerous fistulated nodules about $2-3 \mathrm{~mm}$ in diameter, in the proventriculus wall. Globular nematode parasites were also found inside these nodules.

The worms found in the lumen of the proventriculus were filiform and white. Those removed from the proventriculus nodules were globular and red. The body was enlarged in the middle, thin at the extremities and had transversal striated cuticles. Worms collected were fixed in heated AFA solution $\left(70^{\circ} \mathrm{C}\right)$. Morphologic and morphometric analyses were performed in phenol-clarified worms using a computerized image analysis system (Qwin Lite 2.5 - Leica).

Morphologic analysis revealed that the filiform worms were males and the globular ones were females of the genus Tetrameres. The species was identified after the morphometric analysis of 6 male specimens. The following characteristics were recorded: length, $5315.9 \mu \mathrm{m}$ (4918.1$5917.7 \mu \mathrm{m})$; width, $116.1 \mu \mathrm{m}$ (100.6-133.8 $\mu \mathrm{m})$; buccal capsule, $30.5 \mu \mathrm{m}(27.9-32.9 \mu \mathrm{m})$ in length and $9.3 \mu \mathrm{m}(8.1-11.4 \mu \mathrm{m})$ in width. The two unequal spicules were $309.2 \mu \mathrm{m}(274.0-343.7 \mu \mathrm{m})$ and $118.4 \mu \mathrm{m}(104.3-129.8 \mu \mathrm{m})$ in length. The distance from the cloacal opening to the posterior extremity was $204.7 \mu \mathrm{m}(197.1-212.1 \mu \mathrm{m})$ (Fig. 1). Females were not studied. Based on morphologic and morphometric analyses, the species was identified as Tetrameres americana (Cram, 1927; Vicente et al., 1995). However, Zago Filho and Pereira Barreto (1962) described $T$. americana as a synonym of $T$. confusa (see Travassos, 1919). 


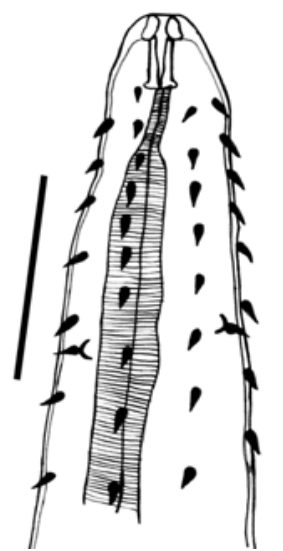

A

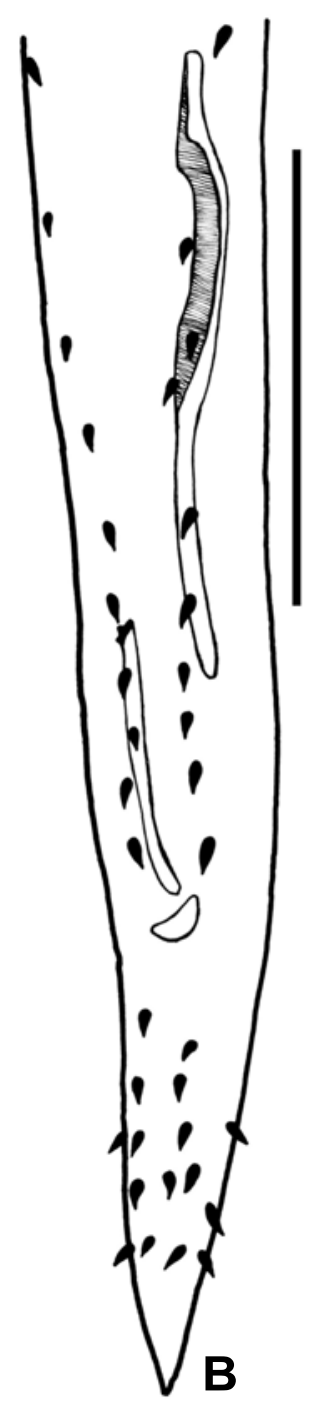

Figure 1. Male Tetrameres confunsa (Nematoda, Tetrameridae) from Ara ararauna (Aves, Psittacidae): A- anterior end. (bar scale $=100 \mu \mathrm{m})$; B- posterior end. (bar scale $=200 \mu \mathrm{m})$.

Species of the Tetrameres genus have a heteroxenic cycle in which the birds are the definitive hosts (Soulsby, 1988). Eggs containing a fully developed first-stage larva are deposited by the female in the proventriculus lumen and eliminated in the feces. Each egg hatches the first-stage larvae penetrate the gut wall and enter the hemocoel of an aquatic crustacean (amphipods, cladoceans) or of a terrestrial insect and isopod, where development of a third and infective stage larva takes place. After several days, these larvae become encapsulated. Birds become infected by ingesting these intermediate hosts harboring encysted third-stage larvae (Anderson, 2000). Zago Filho and Pereira Barreto (1962) described six grasshopper species as intermediate hosts as T. confusa: Eutryxalis filata filata (Walk), Orphulella punctata (De Geer), Dichroplus punctulatus (Thumb), Schistocera cancellata (Serv), Neoconocephalus infuscatus (Scudd), and Caulopsis oberthuri (Bolivar).

Blue-and-gold macaws in the wild are canopy dwellers and can be found in large colonies at the top of trees or near the river edges, where they 
consume clay from the washed out banks. It is believed that the clay provides needed minerals or may aid digestion. These birds like to consume "bacuri" (Platonia insignis) coconuts and "jatobá" (Hymeneae courbaril) fruits and, mainly, "pequi" (Caryocar brasiliensis) (Sick, 1997). Thus, it is likely that the A. ararauna infection by Tetrameres reported here occurred by the ingestion of infected orthopteran insects during food or clay ingestion.

Occurrences of Tetrameres spp. infections in Brazilian birds were reported by Vicente et al.
(1995). Thirteen species of this genus have been identified, however, Tretameres species could not be identified in 11 different reports. Tetramerid nematodes have a wide geographical distribution and have been found in almost all Brazilian States, infecting a wide diversity of hosts. However, there are no records on the occurrence of Tetrameres sp. in psittacids. As a result this is the first report of tetramerid nematode in $A$. ararauna.

Keywords: Tetrameres confusa, Nematoda, Ara ararauna, Psittacidae, new host

\section{RESUMO}

Relata-se a ocorrência de Tetrameres confusa Travassos 1917 (= T. americana (Cram, 1927) Baylis, 1929) (Nematoda, Tetrameridae) em um novo hospedeiro, Ara ararauna Linnaeus, 1758 (Aves, Psittacidae). Este é o primeiro registro da ocorrência do nematódeo em psitacídeos no Brasil.

Palavras-chave: Tetrameres confusa, Nematoda, Ara ararauna, Psittacidae, novo hospedeiro

\section{REFERENCES}

ANDERSON, R.C. Nematode parasites of vertebrates: Their development and transmission. 2.ed. Wallingford, Oxon (UK): CABI Publishing, 2000. 672p.

CRAM, E.B. Bird parasites of the suborders Strongylata, Ascaridata and Spirurata. U.S. Nat. Mus. Bull., v.140, p.1-140, 1927.

SICK, H. Ornitologia Brasileira. Rio de Janeiro: Nova Fronteira, 1997. 862p.
SOULSBY, E.J.L. Parasitología y enfermidades parasitarias en los animales domésticos. México: Interamericana, 1988. 354p.

TRAVASSOS, L. Tetrameridae brasileira. Braz. Med., v.31, p.65-66, 1917.

VICENTE, J.J.; RODRIGUES, H.O.; GOMES, D.C. et al. Nematóides do Brasil. Parte IV: Nematóides de aves. Mem. Inst. Oswaldo Cruz, v.12, Suppl. 1, p.1273, 1995.

ZAGO FILHO, H.; PEREIRA BARRETO, M. Contribuição para o conhecimento dos hospedeiros intermediários da Tetrameres confusa Trav., 1917 (Nematoda, Spiruoidea). Rev. Brasil. Biol., v.22, p.3337, 1962. 